\title{
Teacher Power in EFL Classroom: Associations with Classroom Interaction
}

\author{
Mengistu Anagaw \\ Debre Markos University, Ethiopia \\ Yalemwork Mossu \\ Debre Markos University, Ethiopia
}

\begin{abstract}
Instructional communication is a field that studies behaviors that facilitate leaning in classroom communication. One among these behaviors is teacher power which refers to the transactional process where in teachers are granted different power bases. This study tried to investigate teacher power bases in terms of classroom interaction by involving a writing skills teacher and his 30 students in a first year writing classroom. The students responded to a questionnaire and the lessons were audio recorded and transcribed. Binary logistic regression was computed to see how the teacher power bases relate with classroom interaction permissibility while qualitative data is transcribed and thematically analyzed. The results indicated that the teachers' major power originates from legitimate and expert power bases as well as reward sources and this is negatively associated with classroom interaction. Therefore, it is suggested that the teacher bases his lessons on alternative power sources that can permit students interactions.
\end{abstract}

Keywords: teacher power, teacher power bases/ sources, classroom interaction\& classroom interaction patterns DOI: $10.7176 /$ JLLL/59-02

Publication date: August $31^{\text {st }} 2019$

\section{Introduction}

Instructional Communication as a multifaceted concept is central to the classroom success that it has made McCroskey \& Richmond (1983) to contend '...communication is the teaching process'. As such, instructional communication can be used to fulfill three important functions: to inform, to relate, and to influence others (Booth-Butterfield, 1992). In order to effectively inform and persuade students, behaviors that confirm student identities, build rapport, and facilitate interpersonal relationships appear desirable. Teacher power is one area of classroom communication research that has received considerable attention in the past three decades among such behaviors (Kearney, et al, 1985; Goodboy, et al; 2011).

Teacher power is conceived as "an individual's potential to have an effect on another person's or group of persons' behavior (Richmond, et al, 1980) yet power can't be taken as an attribute of teachers rather power is a property of the social relations. For instance, teachers and students negotiate power and the task of negotiating power between students and instructors shows how they choose to interact (Goodboy, et al, 2011). In this regard, power, is defined as "the teacher's ability to influence students to do something they would not have done had they not been influenced" (Kearney et al., 1984). Hence, teacher power is an important component of instructional communication.

Based on French and Raven's (1959) typology of relational power, Richmond and McCroskey (1984) identified five teacher power bases which embrace coercive power (i.e., the ability to punish or remove rewards), reward power (i.e., the ability to grant rewards to or remove punishments), legitimate power (i.e., the power an instructor possesses for being a teacher), expert power (i.e., the possession of knowledge and competence in a subject area), and referent power (i.e., the ability to be deemed likable). Seen from such perspectives, power is a negotiated construct and not a personal attribute. Of the five power bases, Richmond and McCroskey (1984) contends that instructors should avoid the use of the coercive and legitimate i.e., antisocial power bases and exploit the expert, referent, and to a lesser extent, reward i.e., prosocial power bases. Schrodt et al. (2008) underlines the use of " "... prosocial and antisocial power sources influences different instructional outcomes in different ways.",

Studies have confirmed that teachers' use of power strongly influences teacher-student relationships, students' motivation to learn, and learning outcomes (Finn, 2012; Mottet, et al, 2006; Teven \& Herring, 2005). Classroom interaction which is presumed to follow predictable patterns is one manifestation of relationships. For instance, the IRE initiation-response-evaluation and IRF initiation-response-feedback/follow up patterns of interaction are apparent elements of a traditional lesson giving extensive power to teachers (Cazden, 2001; Walsh, 2011). Both patterns of interaction are started with teacher initiation followed by the students' response to which teachers give a feedback.

Although research on teacher power has provided a solid theoretical foundation of the associations between power and its positive impacts, research has yet to ascertain whether and how instructors' use of either of power 
bases affects classroom interaction. Moreover, studies revealing the patterns of interaction of teachers as well as major power bases of teachers are not available. Thus, this study intends to investigate how teacher power bases associate with classroom interaction.

\subsection{Statement of the problem}

There is "a difference between knowing [a subject matter] and teaching [its contents], and that difference is communication in the classroom" (Hurt, et al, 1978:.3). Moreover, teachers communicate from a base of relational power to influence, inform or to relate with students so that they achieve learning outcomes (cf. Turman \& Schrodt, 2006). As of Reid, \& Kawash, (2017) 'the types of conversations we hold or avoid with students send cues regarding how we use power to develop relationships, influence behavior and induce motivation.' Interaction in the classroom is therefore highly influenced by such power use cues in a teachers' communication. As of (Vygotsky, 1978) learning is conceptualized as a social process that occurs during interaction with an expert, a teacher or peer. This interaction is defined as the "collaboration of thought, feeling, or ideas between two people, resulting in a reciprocal effect on each other" Brown (2007: 212). Thus, such an interaction builds reciprocity for tasks involve students and their teacher as active interactants negotiating power. In such a process of interaction, learners can expand "their own L2 knowledge and extend the linguistic development of their peers" (Donato, 1994:52).

Surprisingly, there are knowledgeable and hardworking teachers who enter class well prepared but fail to deliver their lesson effectively which might be due to ineffective use of communication skills to engage, inform or relate with learners (Nurzali Ismail and Khairu'l Najmi Idris, 2009). Part of this might be attributed to a teachers' power use while interacting with the students. For teachers not well trained on classroom communications, the use of power and power sources might cause students' disengagement or disruptions unless reciprocity is ensured. The type of power base teachers adopt and the way students perceive it along with its impacts on learners' interactions plays a critical role in this regard. Therefore, it's imperative and timely to study a teacher's power use during her/his instructional communication emphasizing how teacher power base associates with classroom interaction. Thus, this study intends to identify major power bases of teachers, determine the classroom interaction patterns and uncover how teacher power base associates with the classroom interaction.

\section{RESEARCH METHODOLOGY}

The main objective of this study is investigating how teacher power bases associate with classroom interaction. A mixed method concurrent exploratory design (Creswell, 2012) which is informed by the pragmatic approach is used. Quantitative data on teacher power bases and qualitative data on classroom interaction and interaction patterns has been gathered through a questionnaire and classroom interaction analysis secured via audio recordings.

The target population of this study has been students and EFL teachers in DMU taking the course writing skills. Participation was merely based on willingness of instructors for classroom observation within the available time frame. Hence, the first teacher who volunteered for the study was considered purposively. Moreover, all of the students in the teachers' classroom are involved for the questionnaire. This study employed the Teacher Power Use Scale (TPUS) questionnaire developed by Schrodt et al. (2007) and classroom audio recording as a major data gathering tools to get a direct insight into how the EFL teachers' power base associates with classroom interaction.

The data on teacher power base is organized and analyzed through the use of SPSS 20 (Statistical Package for Social Sciences) computer programs. Based on the issues raised, data is described using simple descriptive statistics to identify the most and least frequent power base teachers adopt. Moreover, these data is analyzed using binary logistic regression to infer the association of teachers' power base with the extent to which students are allowed to interact. The qualitative data on teachers' expressions of power and interaction patterns is identified from their classroom interactions and it is analyzed thematically.

\section{RESULTS AND DISCUSSION}

The main objective of this study is investigating how teacher power bases associate with classroom interaction Along with this objective, research questions are posed. The research questions necessitated the use of a mixed method concurrent exploratory design (Creswell, 2012) which is informed by the pragmatic approach.

The findings from questionnaire are presented first followed by qualitative data from the analysis of classroom interaction of a teacher. 


\subsection{Teacher power bases}

Table 1: the perceived power bases of the teacher

\begin{tabular}{|l|r|r|}
\hline & Mean & Std. Deviation \\
\hline Coercive & 14.70 & 8.895 \\
Rewards & 19.37 & 5.068 \\
Referent & 17.97 & 6.316 \\
Legitimate & 22.37 & 6.698 \\
Expert & 20.40 & 6.926 \\
& & \\
\hline
\end{tabular}

The mean value of students who reported that their teacher use legitimate power base and those who reported expert power base is found to be higher $(22.3,20.4$ respectively). As revealed from classroom interaction, the teacher used multiple power basses including legitimate and expert as well as reward power in varied ways. Conversely, the mean value of coercive and referent power bases were the lowest $(14.7,17.97$ respectively).

The power base of the teacher is also reflected in the classroom interactions. In the first place the teacher dominated the lesson lecturing for majority of the lesson time including asking and even answering questions. This coupled with how structured and organized the lesson is, justifies the fact that the teacher predominantly depends on expert power.

Driving through the mountains, several beers were seen..... This is a problem because what

drove through the mountain is not known. Who drove through the mountain is not specifically

known. And who saw several beers has not been specifically mentioned. So this can be corrected in the following way.

Driving through the mountains, I saw several beers. I saw instead of saying driving through the mountains, several beers were seen.

In this excerpt, the teacher depended on expert power base. The teacher has asked questions and provided answers himself. The teacher has denied students the chance to try to correct the error thereby communicating expert power inherently. As the lesson proceeded the teacher communicated the following strengthening the above claims.

T: I can give another example.

Having gone to Gondar, the castle was visited. If you look at these two sentences, these two sentences have got errors. And the error type is known as dangling modifier. Who drove through the mountains? We don't know. It looks that several beers were driving through the mountains which is wrong.

Instead this sentence could have been written in the following way.

Driving through the mountains, the student saw several beers.

Driving through the mountains, I saw several beers.

Driving through the mountains, the women saw several beers.

Driving through the mountains, the teacher saw several beers. It can be written this way.

Here the doer of the action is the students. Who drove through the mountains- the students. Who saw several beers- the students. The Students saw several beers.

In this excerpt, it is clear that the teacher depended on his expert power when he gives examples of his own. In the same way, the teacher depended on his own expert power when he decides the two sentences are erroneous and asks questions on as to why the sentences are erroneous. This is followed by the teachers' correction of the sentences and explanations on the corrected sentences. As we can infer from the above excerpt, the teacher gave the examples himself, made the claim that the two sentences 'these two sentences have got errors' raising questions like 'Who drove through the mountains?' and giving answers 'We don't know' and ending up with the teachers revised versions and its justifications. This has been the recurring pattern of interaction during the lessons.

The same pattern is followed in the forthcoming extract.

Riding my bicycle, a dog chased me. Who was riding a bicycle? According to the sentence. It looks that it was a dog. A dog! Which is wrong. So the word modifies what it shouldn't modify. Riding my bicycle, a dog chased me means a dog ride the bicycle and chased me. That is what the meaning is. The dog was riding. The dog driving. The dog chased me driving a bicycle]... so who can correct it? Who can rewrite it? yes!

Student: when I was riding my bicycle,

Teacher: : when I was riding a bicycle, when I was riding a bicycle,

Student: the dog chased me.

Teacher: a dog chased me. a dog chased me. When I was riding a bicycle, a dog chased me. That is 
how it should be corrected.

In doing exercise, the teacher supplied most of the answers himself however a creating learning space (Walsh, 2011) could have been possible if the teacher insist on waiting and pausing to let students respond. The teacher could have waited a bit longer for students to respond on who was riding my bicycle while inviting students to spot modifier errors themselves. However, the teachers' reliance on expert power made him supply organized responses (Schrodt et al, 2008). As a result, the teacher asked a question, described the fault and provided the answer himself, leaving no room for the students self-correction and interaction with the teacher.

The other power base the teacher was observed using was reward power. The teacher used praises in the very few instances where students responded to questions posed.

What about number three? Chopping the onion, the knife cut her finger. Yes?

Student: when she chopping the onion, the knife cut her finger.

Teacher: again?

Student: when she chopping the onion, the knife cut her finger.

Teacher: very good. Who was chopping the onion? In this sentence it looks that it was the knife. It was

the knife itself. The knife by itself was chopping the onion. Which is wrong.

While I Was chopping the onion, the knife cut my finger or

When she was chopping the onion she cut her finger by the knife. Or

While I Was chopping the onion, While I Was chopping the onion, I cut my finger by the knife.

Moreover, in the above excerpt, the teacher asked a question to which a student made an attempt, yet with minor error. The teacher praised the effort implying the adoption of reward power base. Meanwhile, the teacher avoided explicit repair by requesting the student repeat and then telling the correct sentence himself indirectly which enhances involvement and avoids disrupting the interaction (Seedhouse, 2004). This could enhance the students' interaction with the teacher.

In spite of the small sample size making the findings preliminary, the analysis revealed that a teacher's classroom interaction is significantly influenced by teacher power base. The most frequent power base of the teacher as reported by students is legitimate and expert power base. On the other hand, coercive power base is used least followed by referent power source. Analysis of the audio recordings of two lessons revealed that the teacher adopts expert power base followed by rewards power source in a number of instances.

\subsection{Classroom interaction patterns}

This section tried to address how the classroom interaction looks focusing on teacher- student interaction. The quantitative data collected using the questionnaire revealed that the teacher gives chance for students make interactions. This is supported by $36.7 \%$ who admitted that their teacher lets them interact while majority of the students $(63.3 \%)$ conferred that their teacher never lets them make interactions.

Table 2: Does your teacher allow you to make interactions during lessons?

\begin{tabular}{|l|r|r|}
\hline $\begin{array}{l}\text { Does your teacher allow you to make } \\
\text { interactions during lessons? }\end{array}$ & Frequency & Percent \\
\hline Yes & 11 & Cumulative Percent \\
No & 19 & 63.3 \\
Total & 30 & 100.0 \\
\hline
\end{tabular}

Similarly, the analysis of classroom conversation reveals the teacher highly depended on a one directional teacher talk where students got very little time to make interactions among themselves and with the teacher. In those circumstances, the teacher takes the initiation role and then leaves no room for students to respond which when substantiated with proper feedback and follow up could enhance interaction and motivation.

The following excerpt from the second lesson propounds this claim.

There are three reasons why Canada is one of the best countries in the world. This is the topic sentence. There are three reasons why Canada is one of the best countries in the world. The topic is Canada. It is a very broad topic. By the way on the topic you can write a books. Books might be written about Ethiopia. If I give you the topic. Books have been written, books will be written about Ethiopia. If I ask you write a paragraph you need control the topic. This writer has controlled the broad topic in the topic sentence. There are three reasons why Canada is one of the best countries in the world. This writer will write only about the reasons why Canada is one of the best countries in the world. What are the reasons? The reasons will be stated in the body of the paragraph. First, Canada has an excellent health care system. This is the first reason why Canada is one of the best countries. This is. We call this major supporting detail. All Canadians have access to medical services at a reasonable price. This is the first minor supporting detail. Second, the second reason, by the way... first second, finally will give coherence to the paragraph. Canada has a high standard of education. Students are taught by well trained teachers and are encouraged to continue studying at university. Finally, 
Canada's cities are clean and efficiently managed. Canadian cities have many parks and lots of space

for people to live. As a result, Canada is a desirable place to live....

In this extended extract based on a paragraph, the teacher announced the topic sentence, the major and minor supports as well as the concluding sentences right away. He told the topic and controlling idea, made judgments on the breadth of the topic and reminded the cohesive devices and their purpose. So what can students have to interact during the lesson if we uptake learning is all about interaction.

The following excerpt differs in a number of respects. As usual, the teacher takes the initiation by posing a question. The teacher gave the erroneous sentence and makes important inquiries. The teacher asks who is to write effectively and answers it himself. If the teacher waited for a while and let students attempt, it might have simplified the issue of dangling modifiers besides enhancing students' interactions. The pattern of interaction goes on likewise excluding students when the teacher gives alternative resolutions to the erroneous sentences leaving no room for students contributions once again.

To write effectively... To write effectively, practice is necessary. ..who is to going to write effectively?

We don't know. Who is there to practice? We don't know. To write effectively, you must practice. To

write effectively, I must practice.

To write effectively, the students must practice. 'The students' are there to be modified.

To write effectively, you must practice. You. If you want to write effectively, you must practice. You must

practice.

The forthcoming quote from the classroom interaction provides a slightly different dimension to the pattern of interaction observed in the preceding instance. While the teacher takes the initiation by posing the question and elaboration on why the sentence is erroneous, the correction was supplied by a student. However, the students' response was interrupted by the teacher.

T: Riding my bicycle, a dog chased me.

Who was riding a bicycle? According to the sentence. It looks that it was a dog. A dog! Which is wrong. So the word modifies what it shouldn't modify. Riding my bicycle, a dog chased me means a dog ride the bicycle and chased me. That is what the meaning is... so who can correct it? Who can rewrite it? Yes!

Student: when I was riding my bicycle,

Teacher: when I was riding a bicycle, when I was riding a bicycle,

Student: the dog chased me.

Teacher: a dog chased me. A dog chased me. When I was riding a bicycle, a dog chased me. That is how it should be corrected.

In a section of the lesson that focused on misplaced modifiers, the teacher asked a question and appreciated student performance as can be understood from his high pitch, yet the student was interrupted. Restating the response of a student, by using his loudness the teacher expressed his appreciation implying the use of rewards power. Such teacher interruptions have a multitude of negative implications even when that is done based on the IRF pattern (cf. Esra Yataganbaba, Rana YÕldÕrÕm, 2016).

Teacher: Number four? A man drove past in a small ship that was completely bald.

Student: a man that was completely bald.

Teacher : a man that was completely bald. That was completely bald modifies the subject. A man.[fully

bald is who? The man]. A man that was completely bald. Bald.

From the four extracts presented above, it can be inferred that the teacher followed a monological (Christoph \& Nystrand, 2001) rather than a dialogical interaction that occurs when the teacher's voice is prevalent in the classroom. The teacher dominated the lessons at the expense of interactions. Findings of Adaba (2017) on students poor involvement in speaking interaction and teachers dominance relates to this findings.

\subsection{Teacher power base and classroom interaction pattern trajectory}

The way a teacher proceeds from initiation to feedback and follow-up through students' response is considered as the pattern of classroom interaction. However, how the pattern of interaction and power base operate needs a critical study. In this section an attempt is made to show how teacher power base associates with classroom interaction based on data from questionnaire and analysis of classroom interaction.

The table below shows findings from the binary logistic regression analysis carried out. Hence, the table shows that a unit of change in the use of coercive power in the teachers interaction is (odds=1.058) likely to prohibit students interaction. Similarly, a raise in a unit of expert power is (odds $=1.058)$ likely to prohibit students classroom interaction. The use of referent and legitimate power on the other hand are less likely to prohibit classroom interaction. 


\begin{tabular}{|rl|r|r|r|r|r|r|}
\hline & \multicolumn{1}{|c|}{ B } & \multicolumn{1}{c|}{ S.E. } & \multicolumn{1}{c|}{ Wald } & df & \multicolumn{1}{c|}{ Sig. } & Exp(B) \\
\hline \multirow{2}{*}{ Step $1^{\mathrm{a}}{ }^{\mathrm{a}}$} & Coercive & .056 & .078 & .520 & 1 & .471 & 1.058 \\
& Rewards & .260 & .170 & 2.344 & 1 & .126 & 1.297 \\
& Referent & -.007 & .156 & .002 & 1 & .967 & .993 \\
& Legitimate & -.424 & .237 & 3.194 & 1 & .074 & .655 \\
& Expert & .461 & .222 & 4.300 & 1 & .038 & 1.585 \\
& Constant & -5.033 & 3.219 & 2.444 & 1 & .118 & .007 \\
\hline
\end{tabular}

The classroom interaction mostly starts with teacher initiation of the communication by asking questions. However, the students are rarely given time and chance to respond to questions making it doubtful if a specific pattern is practiced. The only exception to this is the following excerpt.

$\mathrm{T}$ : What is the topic for the first topic sentence? [Initiation]

S: cooking [response]

$\mathrm{T}$ : cooking is the topic sentence. What about the controlling idea [follow up echo and initiation 2]

Ss: different skills [response]

T: different? [follow up]

Ss: skills. [response]

$\mathrm{T}$ : So the writer will write only about cooking in terms of the different skills that is required [ so it will

focus the different skills not the importance of cooking] [follow up]

$\mathrm{T}$ : hobbies provide people with many benefits? What is the topic? [Initiation]

S: hobbies [response]

$\mathrm{T}$ : the controlling idea

S: many benefits [response]

$\mathrm{T}$ : many benefits. You will write the many benefits that hobbies have.

However, Cazden (2001) labels such questions are all inauthentic display questions unlikely to improve interaction and this stems out of a teachers desire to control things implying the use of expert power.

Another feature of the interaction pattern consistently practiced was Teacher-teacher echo: where the teacher repeats his own mostly responses and questions (utterances) that were not meant for restatement purposes yet casually practiced against students' interactional space opportunities since the teacher is taking up learners' space in the dialogue. From among the possible instances where the teacher echoed himself, the following is one where the teacher repeated two utterances needlessly.

At the age of four, my parents took me to Addis Ababa. If you look at this sentence, the phrase looks to modify my parents. It looks that my parents were four when they got to Addis Ababa. . It looks that my parents were four when they got to Addis Ababa. It is wrong. When I was four, When I was four my parents took me to Addis Ababa. When I was four, my parents took me to Addis Ababa. This is possible. At the age of four, at the age of four, I was taken to Addis Ababa. At the age of four, I. who was four? I. so this can be corrected in two ways. One When I was four my parents took me to Addis Ababa. Second, at the age of four, I was taken to Addis Ababa by my parents.

The teacher could have created a very appetizing and engaging learning space if students were participated, for instance, to determine what is wrong in the given sentence, what the unintended meaning is and what is being modified unexpectedly. This could have made the effort of correcting the sentence simple and engaging.

Another instance of teacher echo can be noticed in the following extract. In this case, the repetitions neither contributes to the focus of the lesson nor does it imply a restating purpose for something that could be missed by students. Besides, repeating only ten needlessly, the teacher made a nearly the same echo for its own sake.

He only left ten minutes ago. Only ten. Only ten! He left only ten. Only one. Only two. Only three.

Nearly three. Almost three. Almost four. Such modifiers appear.

While the 'traditional' IRE \& IRF patterns of interaction advocate a stringent and solid pattern of classroom interaction, Cazden (2001) the nontraditional lesson does not follow this sequence and allows for more student responses and topic expansion based on 'metacognitive, questions'. Similarly, (Walsh, 2011) advises teachers' increase pauses, acknowledge contributions, minimize interruptions, allow extended learner turns and make follow up turns requiring explanations, pushing for more information, and asking more guiding questions instead of filling in the gaps or making repairs. Conversely, the teacher let students make utterances quite few times answering questions himself in a good number of instances. This can be attributed to power relations conceived by the teacher (cf. Lin, 2000). Cazden (2001) implies that the adoption of the IRE/ IRF interaction pattern reserves power for teachers to control the flow of information and the progress of a lesson.

\section{CONCLUSIONS AND RECOMMENDATIONS}

This current study aims to investigate teacher power bases in relation to classroom interaction in EFL basic 
writing skills classroom. Classroom interaction data was audio recorded for two lessons. The students in that particular class were also participated to fill out the questionnaire the data from questionnaire and audio recordings is analyzed separately but presented together accordingly the following conclusions are drawn.

\subsection{Conclusions}

The following conclusions are drawn based on the analysis carried out.

1. Legitimate and expert power bases comprise the major power bases of the teacher. The classroom interaction revealed that the teacher predominantly bases his communication of power on expert and some extent to reward bases.

2. The teachers' dependence on expert power is responsible for the teachers' dominance of the classroom interaction.

3. The teacher did not strictly follow the Initiation- response evaluation or Initiation- response feedback /follow up pattern. He simply ask, direct, and led the entire class through teacher-whole-class interaction in most cases. Reciprocity was reduced.

4. Concerning the interaction patterns in language classroom, the audio recorded classroom interaction revealed that the teacher not only initiate but also respond and evaluate his utterances leaving students no space for learning.

\subsection{Recommendations}

1. The power base of the teacher in situations where interactions are highly demanded requires careful reconsideration of the teacher. The teacher should make efforts to adjust power base which in turn would affect interactions.

2. Because the teachers' dependence on expert power is responsible for the teachers' dominance of the classroom interaction, it would be plausible to suggest consideration of alternative power bases that can facilitate interaction to enhance reciprocity.

3. In those instances where the teacher was interacting with the students, the teacher did not reserve much time for students and doing so might enhance students interaction. In giving feedback and follow ups, the teacher could make improvements asking metacognitive and rebound questions instead of display items.

\section{References}

Adaba HW (2017) Exploring the Practice of Teacher-Student Classroom Interaction in EFL to Develop the Learners' Speaking Skills in Tullu Sangota Primary School Grade Eight Students in Focus. Arts Social Sci J 8: 295. doi: 10.4172/2151-6200.1000295

Barnes, D. (1992). From communication to curriculum. Portsmouth, NH:Boynton/ Cook.

Booth-Butterfield, S. (1992). Influence and control in the classroom. Edina, MN: Burgess Publishing.

Boyd, M. \& Maloof, V.M. (2000). How teachers can build upon student-proposed intertextual links to facilitate student talk in the ESL classroom. In J.K. Hall \& L.S. Verplaetse (Eds.), Second and foreign language learning through classroom interaction (pp. 163-182). Mahweh, NJ: Lawrence Erlbaum.

Brown, H. D. (2007). Teaching by principles: An interactive approach to language pedagogy. New York: Pearson Education.

Christoph, J.N., \& Nystrand, M. (2001). Taking risks, negotiating relationships: One teacher's transition toward a dialogic classroom. Research in the Teaching of English, 36(2), 249-286.

Donato, R. (1994). Collective scaffolding in second language learning. In J. A. Lantolf, \& G. Appel (Eds.), Vygotskian approaches to second language research (pp. 33-56). Westport, CT: Ablex.

Flanders, N. (1970). Analyzing teaching behavior. Reading, MA: Addison-Wesley.

Fin, A.N. (2012). Teacher use of prosocial and antisocial power bases and students' perceived instructor understanding and misunderstanding in the college classroom. Communication Education, 61(1)1, 67-79.

French, J.R.P., \& Raven, B.H. (1968). The bases of social power. In D. Cartwright \& A. Zander (Eds.), Group dynamics: Research and theory (pp. 259270). New York: Harper \& Row.

Goodboy, K., Bolkan S., Myers Scott A \& Xing Zhao (2011) Student Use of Relational and Influence Messages in Response to Perceived Instructor Power Use in American and Chinese College Classrooms, Communication Education, 60:2, 191-209.

Hurt, H. T., Scott, M. D., \& McCroskey J. C. (1978). Communication in the classroom. Reading, MA: AddisonWesley.

Kearney, P., Plax, T. G., Richmond, V. P., \& McCroskey, J. C. (1984). Power in the classroom IV: Alternatives to discipline. Communication Yearbook , 8, 724-746.

McCroskey, J. C., \& Richmond, V. P. (1983). Power in the classroom I: Teacher and student perceptions. Communication Education, 32, 175-184.

Nassaji, H. \& Wells, G. (2000). What's the use of 'traidic dialogue'?: An investigation 
of teacher-student interaction. Applied Linguistics, 21 (3), 376-406.

Reid, L. F., \& Kawash, J. (2017). Let's talk about power: How teacher use of power shapes relationships and learning. Papers on Postsecondary Learning and Teaching: Proceedings of the University of Calgary Conference on Learning and Teaching, 2, 34-41.

Richmond, V.P., \& McCroskey, J.C. (1992). Power in the Classroom: Communication, Control, and Concern. Lawrence Erlbaum Associates, Inc, New Jersey

Richmond, V.P. (1990). Communication in the classroom: Power and motivation. Communication Education, 39, 181-195.

Richmond, V.P., \& McCroskey, J.C. (1984). Power in the classroom II: Power and learning. Communication Education, 33, 125-136.

Richmond, V. P., McCroskey, J. C., Davis, L. M., \& Koontz, K. A. (1980). Perceived power as a mediator of management communication style and employee satisfaction: A preliminary investigation. Communication Quarterly, 28, 37-46.

Roach, K.D., \& Byrne, P.R. (2001). A cross-cultural comparison of instructor communication in American and German classrooms. Communication Education, 50, 114

Rustandi, A., \& Mubarok, A. H. (2017). Analysis of IRF (Initiation-Respon-Feedback) on classroom interaction in EFL speaking class. Edulite: Journal of English Education, Literature, and Culture, 2(1), 239-250.

Schrodt, P., Witt, P.L., Myers, S.A., Turman, P.D., Barton, M.H., \& Jernberg, K.A. (2008). Learner empowerment and teacher evaluations as a function of teacher power use in the college classroom. Communication Education, 57, 180-200.

Schrodt, P., Witt, P.L., \& Turman, P.D. (2007). Reconsidering the measurement of teacher power use in the college classroom. Communication Education, 56, 308-332.

Teven, J.J., \& Herring, J.E. (2005). Teacher influence in the classroom: A preliminary investigation of perceived instructor power, credibility, and student satisfaction. Communication Research Reports, 22, 235-246.

Turman, P. D., \& Schrodt, P. (2006). Student perceptions of teacher power as a function of perceived teacher confirmation. Communication Education, 55, 265-279.

Vygotsky, L. S. (1978). Mind in society: The development of higher psychological processes. Cambridge, MA: Harvard University Press.

Wells, G. (1993). Reevaluating the IRF sequence: a proposal for the articulation of theories of activity and discourse for the analysis of teaching and learning in the classroom. Linguistics and Education, 5, 1-17.

\section{DEBRE MARKOS UNIVERSITY \\ COLLEGE OF SOCIAL SCIENCES AND HUMANITIES \\ DEPARTMENT OF ENGLISH LANGUAGE AND LITERATURE APPENDIX A: STUDENT QUESTIONNAIRE}

DEAR RESPONDENTS please show your level of agreement to the following statements by putting a tick mark in the column you deem appropriate.

\begin{tabular}{|c|c|c|c|c|c|}
\hline No & Behaviors of the teacher & 1 & 3 & 4 & 5 \\
\hline 1. & $\begin{array}{l}\text { When students do not perform at an acceptable level, my teacher embarrasses them in } \\
\text { class }\end{array}$ & & & & \\
\hline 2. & My teacher belittles or puts down students if they do not perform up to expectations. & & & & \\
\hline 3. & If students question course policy, my teacher responds by acting dictator. & & & & \\
\hline 4. & My teacher punishes students who do not follow his/her instructions. & & & & \\
\hline 5. & My teacher stares at students who misbehave in class. & & & & \\
\hline 6. & When students turn in assignments late, my teacher makes them feel guilty. & & & & \\
\hline 7. & My teacher rewards the class for complying with his/her requests. & & & & \\
\hline 8. & $\begin{array}{l}\text { When a student demonstrates mastery of course material, my teacher appreciates the } \\
\text { student. }\end{array}$ & & & & \\
\hline 9. & $\begin{array}{l}\text { When a student performs well in the course, my teacher gives him/her recognition in } \\
\text { the class. }\end{array}$ & & & & \\
\hline 10. & $\begin{array}{l}\text { My teacher publicly recognizes students who exceed expectations in course } \\
\text { performance. }\end{array}$ & & & & \\
\hline 11. & $\begin{array}{l}\text { When a student follows my teacher's instructions, he/she receives praise from the } \\
\text { teacher. }\end{array}$ & & & & \\
\hline 12. & $\begin{array}{l}\text { When students perform well, my teacher becomes more flexible and willing to } \\
\text { negotiate. }\end{array}$ & & & & \\
\hline 13. & My teacher demonstrates commitment by being real when interacting with students. & & & & \\
\hline 14. & I find myself identifying with my teacher because we have a lot in common. & & & & \\
\hline
\end{tabular}




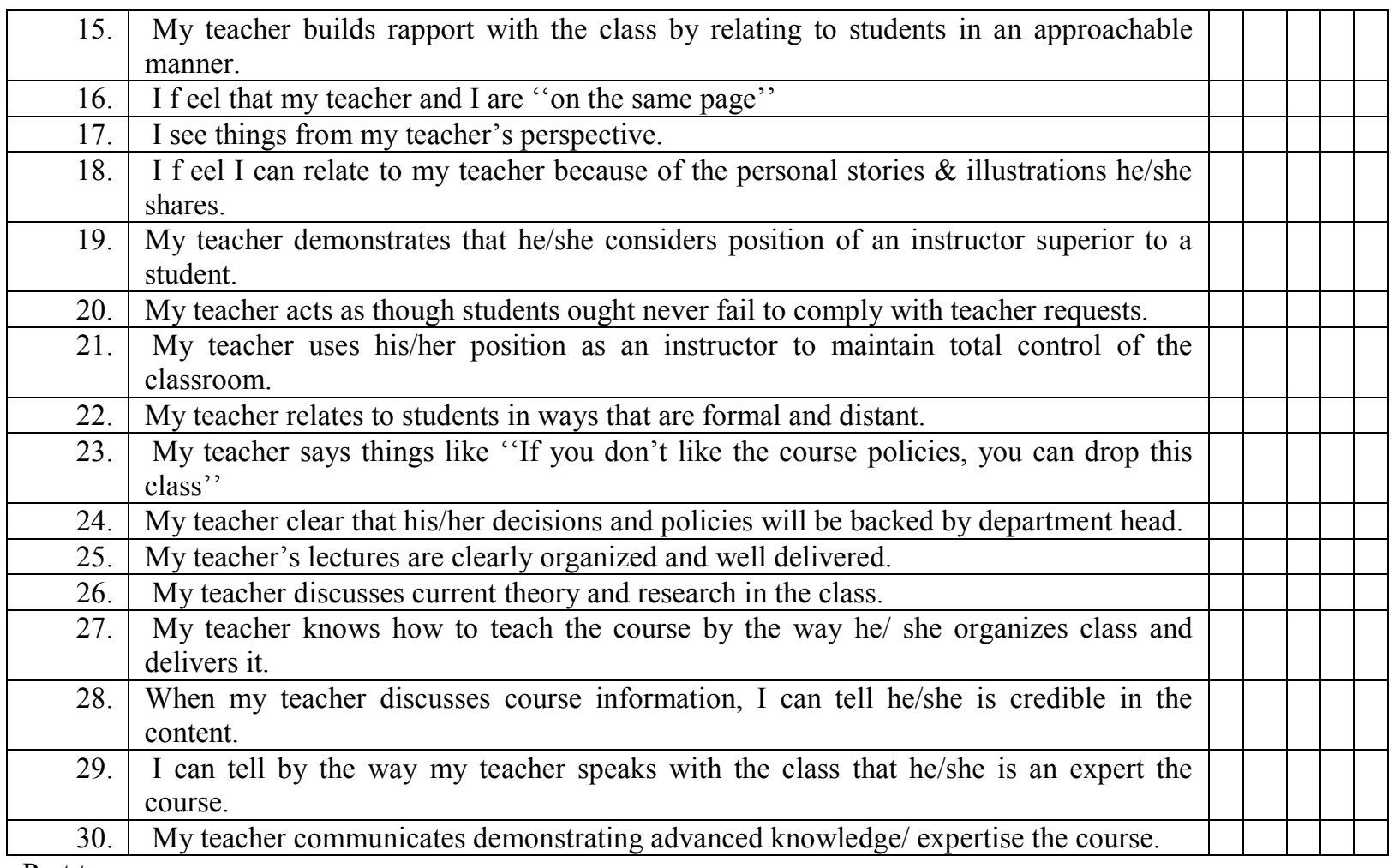
Part two:

1. How often does your teacher allow you to communicate during lessons? Never Rarely Sometimes Usually Always

2. Does any of the behaviors above affect your decision to communicate during your lessons? Yes no

3. If :yes' how much very little little somewhat big big enormous

4. If 'no' do you make any adjustments to communicate in the class?

Lesson one transcription

Teacher (to whole class): Okay, last time we began the second unit of the course and we discussed the major faults that we commit while we are writing sentences and we said that, sentence fragments, run ons and comma splices are the major, the three major that we make while we are writing sentences.

Today we will begin the other fault type which we make while we are writing sentences. The first one that we discuss today is dangling modifiers.

Dangling modifier, I think you know the name dangling modifier. This is a fault type which is made when a word, a phrase or a clause modifies nothing or modifies something which is not supposed to be modified. for example in your handout on page 19 there are certain examples.

Driving through the mountains, several beers were seen.

If you look at this sentence, you don't know who drove through the mountains. We don't know who saw several beers.it has not been clearly stated who saw several beers who drove through the mountains. So this sentence has got a problem. This is a problem because what drove through the mountain is not known. Who drove through the mountain is not specifically known. And who saw several beers has not been specifically mentioned. So this can be corrected in the following way.

Driving through the mountains, I saw several beers. I saw instead of saying driving through the mountains, several beers were seen.

I can give another example.

Having gone to Gondar, the castle was visited. If you look at these two sentences, these two sentences have got errors. And the error type is known as dangling modifier.

Who drove through the mountains? We don't know. It looks that several beers were driving through the mountains which is wrong.

Instead this sentence could have been written in the following way.

Driving through the mountains, the student saw several beers.

Driving through the mountains, I saw several beers.

Driving through the mountains, the women saw several beers.

Driving through the mountains, the teacher saw several beers. It can be written this way. 
Here the doer of the action is the students. Who drove through the mountains- the students. Who saw several beers- the students. The Students saw several beers.

If look at this one Having gone to Gondar, the castle was visited.

Who has gone to Gondar? We don't know. This modifies nothing in the sentence. Or it modifies something which is not supposed to be modified.

Having gone to Gondar, the castle it says.

It looks that the castle went to Gondar. It looks. Which is wrong.

Having gone to Gondar, I saw the castle. I visited the castle. The students visited the castle. The visitors visited the castle. The visitors. Who has gone to Gondar? The visitors. Who has gone to to Gondar? I.

Having gone to Gondar, I visited the castle. I visited the castle. After I had gone to Gondar, I visited the castle. ...

when they had gone to Gondar, they visited the castle.

So it can be corrected in different ways

In short dangling modifier means, it is a fault type which is made when a word, a phrase or a clause modifies nothing in a certain sentence. Or modifies something different from what is supposed to modify.

There are a lot of examples in your handout.

To write effectively... To write effectively, practice is necessary.

Who is to write effectively? We don't know. Who is to going to write effectively? We don't know.

Who is there to practice? We don't know.

To write effectively, you must practice.

To write effectively, I must practice.

To write effectively, the students must practice. The students are there to be modified.

To write effectively, you must practice. You. If you want to write effectively, you must practice. you must practice.

This sentence can be in this way.

On page 19 , there is activity. Activity 18 . Please do activity 18 . Do activity 18 . Rewrite. It has a problem which is known as dangling modifiers. Rewrite the sentences correctly.

Task given

Student 1: why is dangling a modifier error.

Teacher: dangling a problem is just like run on. It is just like sentence fragments. There are other modifier errors that we are going to look at.one type of error or fault. Okay we can together.

1. To lose weight, fatty foods should be avoided. Who is there to lose weight? We don't know. Who is there to avoid fatty foods? We don't know.

Teacher and students: To lose weight, you should avoid fatty foods.

Teacher: if you want to lose weight, you should avoid fatty foods.

2. At the age of four, my parents took me to Addis Ababa. If you look at this sentence, the phrase looks to modify my parents. It looks that my parents were four when they got to Addis Ababa. . It looks that my parents were four when they got to Addis Ababa. It is wrong. When I was four, When I was four my parents took me to Addis Ababa. When I was four, my parents took me to Addis Ababa. This is possible. At the age of four, at the age of four, I was taken to Addis Ababa. At the age of four, I. who was four? I. so this can be corrected in two ways. One When I was four my parents took me to Addis Ababa. Second, at the age of four, I was taken to Addis Ababa by my parents.

3. What about number three? Chopping the onion, the knife cut her finger. Yes.

Student: when she chopping the onion, the knife cut her finger.

Teacher: again?

Student: when she chopping the onion, the knife cut her finger.

Teacher: very good. Who was chopping the onion? In this sentence it looks that it was the knife. It was the knife itself. The knife by itself was chopping the onion. Which is wrong.

While I Was chopping the onion, the knife cut my finger or

When she was chopping the onion she cut her finger by the knife. or

While I Was chopping the onion, While I Was chopping the onion, I cut my finger by the knife. (You may life out by the knife)

4. Riding my bicycle, a dog chased me. Who was riding a bicycle? According to the sentence. It looks that it was a dog. A dog! Which is wrong. So the word modifies what it shouldn't modify. Riding my bicycle, a dog chased me means a dog ride the bicycle and chased me. That is what the meaning is. In Amharic[who was driving. the dog was riding. The dog driving. The dog chased me driving a bicycle]... so who can correct it? Who can rewrite it? yes!

Student: when I was riding my bicycle,

Teacher: : when I was riding a bicycle, when I was riding a bicycle, 
Student: the dog chased me.

Teacher: a dog chased me. a dog chased me. When I was riding a bicycle, a dog chased me. That is how it should be corrected.

5. By checking the answer sheet, my errors become clear to me. What about this one? By checking the answer sheet, my errors. Who checked the answer sheet? It looks that my errors. my errors. my errors checked the answer sheet. That is what the meaning looks. This should be correctly written. Who can who can read the corrected sentence for question number five? Yes!

Student: when I was checked the answer sheet, my errors become clear to me.

Teacher: very good at least you have added a subject (low tone). After I had checked the answer sheet, my errors became clear to me. After I had checked the answer sheet, my errors became clear to me. Who checked the answer sheet? I ...I.

6. What about number six? Going to Egypt, ancient pyramids were visited. Who went to Egypt? We don't know? We don't know? [in Amharic who went to Egypt, we don't know.]

Going to Egypt, ancient pyramids were visited. It is so.

After I had gone to Egypt, I visited the ancient pyramids. After I had gone to Egypt, I visited the ancient pyramids.

7. To master dangling modifiers, hard work is required. What about this one? To master dangling modifiers, hard work is required. To master dangling modifiers, you require hard work. You require hard work. If you want to master dangling modifiers, you must work hard. You must work hard. There must be a subject a noun or a pronoun who does require hard work and who is there to master dangling modifiers. So to master dangling modifiers, you require hard work. You must work hard. It can be corrected in different ways. You must work hard. You require hard work. Etc.

8. To examine the brakes, the wheel must be removed. I think you can correct it yourself.

14:52 The fifth fault type is known as misplaced modifiers. misplaced modifiers. misplaced is wrongly placed. Miss placed modifiers. It means wrongly placed modifier. Modifiers must appear closer to the noun that they modify as much as possible. As much as possible. Modifiers must appear closer to the noun that they modify. If you don't do this, what you write, what you speak will be a mistake. For example:

The man is my friend who is coming. who is coming. Is it right? Is it right? Is it a right sentence? The man is my friend who is coming. Right or wrong?

Students: wrong

Teacher: Right or wrong?

Students: wrong

Teacher : This is a wrong sentence. Because the clause 'who is coming' appears in its wrong place, this should appear closer to the noun that it modify.

The man who is coming is my friend. Who is coming is there to modify the man. It gives essential information about the subject. So it must appear here. The man who is coming is my friend. Such errors are known as misplaced modifiers. There are examples in your handout. Let us look at that.

Their marriage nearly was broken. Their marriage nearly was broken. What does nearly modify? Nearly modifies. Nearly is an adverb. It modifies a verb. It modifies broken. Their marriage was nearly broken. Their marriage was nearly broken. That is ..That is how it should be written.

Abebe performed the role with a dark attitude. Abebe with a dark attitude performed the role. with a dark attitude modifies the subject.

A dog is a good company that is well trained. That is well trained modifies the subject. A dog. A dog that is well trained is a good friend. A dog. A dog that is well trained is a good friend. That is well trained gives very essential information about a dog. The subject. So that is well trained appeared in its wrong place. It is wrong to place that clause at the end of the sentence. It should appear closer to the subject next to the subject. A dog that is well trained. What kind of dog is a good friend? that is well trained that is well trained gives us essential information about the subject- the dog.

By looking at the examples again, I would like you to do activity 19 together. There are similar problems in all ten sentences which are given in activity. Please discuss the examples again and do the activity.

[After a short while the whole class discussion resumed.]

We can discuss together.

1. She borrowed an egg from a neighbor that was rotten. There is a separate clause which is placed wrongly. And that clause should appear in its right place so that the sentence would become meaningful. So who can correct it? an egg that was rotten. An egg. she borrowed an egg that was rotten from a neighbor that was rotten modifies an egg. [in Amharic what type of egg? Rotten. Rotten modifies an egg. She borrowed an egg that was rotten]. It should appear closer to the noun that it modifies.

2. He only left ten minutes ago. Only ten. Only ten! He left only ten. Only one. Only two. Only three. Nearly three. Almost three. Almost four. Such modifiers appear. 
3. I almost read half the book. What about this one?

Student: I read almost half.

Teacher: I read almost half. Almost half. Almost all. Almost three.

4. Number four. A man drove past in a small ship that was completely bald.

Student: a man that was completely bald.

Teacher : a man that was completely bald. that was completely bald modifies the subject. A man.[fully bald is who? The man]. A man that was completely bald. Bald.

5. Number five. The young girl was walking the dog in a short skirt. Ah? What about this one? What does in the short skirt modify? [it is the girl, right? The girl in short skirt ] . the girl in a short skirt the girl in a short skirt was walking the dog. the girl in a short skirt

6. What about number six? Mr. Yassir arefat, ah? who was the first president of Palestine who was the first president of Palestine was born in Jerusalem. So who was the first president of Palestine modifies modifies the subject Mr. Yassir arefat. Mr. Yassir arefat. It should appear closer to next to the noun. The subject.

7. Number seven. The woman is a medical doctor in a green coat. The woman in a green coat. The woman in a green coat is a medical doctor....

Transcript of lesson two.

[No student was involved up to the $21^{\text {st }}$ minutes of the lesson. So this part was left out for it has very little to do with interaction. However an interesting analysis of a paragraph is transcribed to represent other sections]

[10-15' T: On page 24 there is a paragraph. One very interesting paragraph.

There are three reasons why Canada is one of the best countries in the world. This is the topic sentence. There are three reasons why Canada is one of the best countries in the world. The topic is Canada. It is a very broad topic. By the way on the topic you can write a books. Books might be written about Ethiopia. If I give you the topic. Books have been written, books will be written about Ethiopia. If I ask you write a paragraph you need control the topic. This writer has controlled the broad topic in the topic sentence. There are three reasons why Canada is one of the best countries in the world. This writer will write only about the reasons why Canada is one of the best countries in the world. What are the reasons? The reasons will be stated in the body of the paragraph. First, Canada has an excellent health care system. This is the first reason why Canada is one of the best countries. This is. We call this major supporting detail. All Canadians have access to medical services at a reasonable price. This is the first minor supporting detail. Second, the second reason, by the way... first second, finally will give coherence to the paragraph. Canada has a high standard of education. Students are taught by well trained teachers and are encouraged to continue studying at university. Finally, Canada's cities are clean and efficiently managed. Canadian cities have many parks and lots of space for people to live. As a result, Canada is a desirable place to live....

21:09

$\mathrm{T}$ : What is the topic for the first topic sentence?

S: cooking

$\mathrm{T}$ : cooking is the topic sentence. What about the controlling idea

Ss: different skills

T: different?

Ss: skills. So the writer will write only about cooking in terms of the different skills that is required [ so it will focus the different skills not the importance of cooking]

$\mathrm{T}$ : hobbies provide people with many benefits? What is the topic?

S: hobbies

$\mathrm{T}$ : the controlling idea

S: many benefits

$\mathrm{T}$ : many benefits. You will write the many benfits that hobbies have. 